何にして若い教室員に魅力を与え，彼らを引きつけて行 くかといらこてとであります，近頃は，年々沢山の学会 が開催され，実際的で，手軽に発表できるようなテーマ が若い人達から好まれる傾向にあります，そういら状況 下にあって，大内教授は長年に亘り，若い人達加敬遠 されるようなテーマで，若い研究者をひっぱって来た． その牽引力は敬服に値すると思います.

少し個人的な話になりますが，昭和 15 年に，武藤完雄 先生が，杉村先生の後任として，神户の県立病院から東 北大学の教授になられた年，最初の弟子として福島の本 多憲兒教授や大内清太教授など優秀な人物が入局してま いりました．私は，その頃助教授をしていましたが，あ る時, 新入局の大内君に対して，「これから君が関係し た手術については，その所見と自分の反省も加えて記録 し，とつて置くといろいろためになる」ということをす すめたことがありました，後で，大内君のノートを見せ て鿓って，実に丹念に，私が期街した以上に，手術記録 をとっているのをみて感心したのであります。これは後 で判ったことですが，それは私に云われたからでなく， 大内教授はもともと緻密で,メモをよく取っておく習慣 があったからで，大内教授のメモは今でも有名でありま

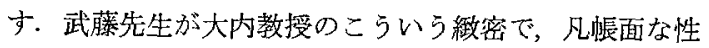
格を見抜いて，生化学の正宗教授のとこるに赲強にやっ たのではないかと推定して招ります，また，正宗一教授 は, 御承知の人す多加万思いますが，九州大学出身 で，ムב物質研究の日本の草分けで，グルクロナイドを 加水分解する酵素，すなわち $\beta$-glucuronidase の存在 世界で初めて確認した先生でもあります，その先生のむ とで，生化学的研究の手汪どきを受けたことが，青年大 内涒の将来に大以溢したものと存じます，要するに， 大内教授は，武藤先生といい，正宗先生といい，上き師 にめぐり合わせたことも倖せだったと思っている次第で

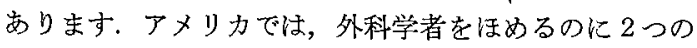

言葉があるように思います。１つ虫，あの人は立派な surgeon であるという表現であります。拉をらく，今 日ご出席の皆様の中にも，たびたびそら云われて来た方 が大勢いるかと存じます．もう1つの場合は，あの人は scientist であると云われる場合であります。そして， これにはいささか尊敬の念がこめられているよらにも感 じら扎ます。本日，私注大内教授に心から great scientist の讃辞を送って，私の発言を終ることにいたしま す、有難らございました。

\section{特 別講 演}

\section{大腸がん治療に於ける私の経験}

東京女子医科大学附属消化器病センター 名举所長中山恒明

私は瀬尾教授のもとでおもに消化器の外科を勉強して おりました. 私の若い頃に瀬尾先生は留の全摘出の後, むしくは胃の幽門部切除の後で小腸のインターポーショ ン一移植手術を行いました，大腸の手術は当時は，現在 の様に抗生物質が使えないので，いわ河る縫合不全が多 くて, 死亡率の高い分野のひとつでありました. これを なく寸為に，血流血行状態の良い小腸をこの切除した大 腸の久損部にインターポーションー移植するといらこと を私法考えして、いろいろな分野にこれを応用いたし ました，そして縫合不全を著しく下げることが出来るよ うになりました. その具体的な例を, 回盲部切除, 横 行結腸切除，そして下行結腸の切除，S状結腸の切除な らびに最後に直腸切断の場合にポールスルー一いるゅる 引き抜きの後大腸が肛門まで届かない時に，この部分に 小腸を移植するといらような手術もやってみたことがあ ります．それ等の成績と，それから具体的な症例を括話 しして，今後のこういった方面の技術的な進歩というむ のの問題点をお話するつもりでおります。

\title{
シンポジゥム I：大腸癌の早期発見と治療方針
}

\section{SI-1. 大腸癌の早期発見}

\section{弘前大学第 1 内科 相沢中，棟方 昭博}

昭和 47 年 7 月より直腸鏡による直腸癌の集団検㟝，昭 和51年12月よりこれに便潜血反応を併用して行っている のでその結果について報告した，受診者は青森県弘前市 近郊の16力市町村の地城一般住民で, 受診者数は 8,554
名であった．受診者の年齢別分布は 30 才代 1,152名，40 才代 2,726 名，50才代 2,620 名，60才代 1,602名で，男性 は2,541名，女性は6,013名とその比は $1: 2.4$ であった。 直晹鏡検診の成績は大䐎癌 9 例 $0.11 \%$, 大腸 ポリープ 174 例 $2.0 \%$, 大腸秃室疾患 3 例 $0.04 \%$, 大腸メラノージ ス28例 $0.33 \%$ であった. 大腸癌 9 例中， 3 例は進行癌で Dukes B 2 例, C I 例であった. 大腸ボリポージスに 合併した39才女性以外はいずれす60才代であった，早期 
癌 5 例は有茎性 1 例, 重有蒸性 4 例で内視鏡的ポリープ 切除を行い診断し，いずれも $\mathrm{m}$ 癌で大きさは最大径 10 $\mathrm{mm}$ 以上であった. 大腸ポリープ174例の年齢別分布は 50 才代63例 $2.40 \% ， 60$ 才代 46 例 $2.86 \%$ に多く，性別では 男性 81 例 $3.19 \%$ ，女性93例1.55\%であった：ポリープは 積極的に内視鏡的ポリープ切除を試み 45 例 $25.9 \%, 51$ 病 変に行った. ポリープ247病変の組織学的検索では213病 変 $86.2 \%$ は腺腫であり, 過誤腫, 若年性, 過形成性, 炎 症性, カルチノイドなどが少数例をしめていた.

便潜血反応惊 5,844 人に併用し，一回目の潜血陽性法 890 例 $15.2 \%$ ，さらに二回目を再検すると 251 例 $4.3 \%$ が 陽性であった. 大腸の精検は 185 例に行い，大腸癌 1 例 $0.02 \%$ ，大腸 ポリープ 6 例 $0.10 \%$ ，大晹恐室疾患 4 例 $0.07 \%$, リンパ滤胞增殖症 2 例 $0.03 \%$ で有病者は 13 例 $0.22 \%$ であった．大腸癌の 1 例は 69 才女性で $\mathrm{S}$ 状結腸と 横行結腸に重複する進行癌であった，直腸鏡による集団 検診は正確な診断ができるなど長所が多いが，診断能に 問題を残すものの便潜血反応によるスイリーニングも有 意義な方法である.

\section{SI-2. スクリーニング険査と 精密検査の立場か らみた大腸癌の早期診断}

\author{
京都第 1 赤十字病院第 3 内科 \\ 多田 正大
}

京都府立医科大学公業衛生

赤坂 裕 三

近年，日本人の間に注大晹癌法漸増してきており，近 い将来, 欧米人並みの高頻度になることも予想されてい る. 大腸癌の予防と撲隇のためには, 早急に予防医学が 確立されなければならないが，同時にその早期診断・治 療む重要である，そこで大腸癌の早期発見のために，大 腸澏検診のあり方について検討を行った。

その結果, 日本人に打ける大腸癌の好発部位, 検查の 効率, 費用, 被験者の苦痛などの点から, 直腸と $\mathrm{S}$ 状結 腸の下部大腸癌検影が最も現実的な検診法であると考え られた. そこで sigmoidofiberscope による検診を行 い，その成績について報告を行ったが，大腸癌の早期発 見のためには，被験者の愁訴の有無にかかわらず，でき るだけ若年者にまで逆のぼって，普遍的に検診が行われ ることが期待される。あわせて，問診や䔬便潜血反応を 検討寸ることが，癌診断の補助的手段として有効である 場合が多いことも強調したい．

\section{SI-3．大腸 pm 癌の診断とその意義}

東北大学第 3 内科 東海林健一.

昭和17年から昭和54年 7 月までに，東北大学第三内科 を訪れ，主として第一外科で，切除術を受けた大晹癌患 者は, stage $\mathrm{V}$ を除くと，244例である。 そのうちわけ は, m 癌 23例, sm 癌 19例, pm 癌 33例, ss, $a_{1}$ 癌 62 例, sa2 澏 78例, si, ai 癌 29例で, リンパ節転移は, 各 々， $0 ， 0 ， 4 ， 20 ， 35 ， 16$ 例に認められた. $\mathrm{pm}$ 癌の相 対生存率は，5年 $92.3 \% ， 7$ 年 $80.5 \%, 10$ 年 $90.3 \%$ で, 7 年目まで徐々に降下し，その後上昇する傾向を示し， リンパ節転移例を除いた29例では，5年99.5\%（95\%信 頼区間 $85.7 \%$ 113.3\%)，10年 96.1\%（95\% 信頼区間 $73.5 \%$ 118.7\%) で，一般人に近い值を示し，進行癌 としては良好な成緽を示している. 病悩期間, 臨床症状 では，他の媣達度の癌との間に差は認められなかった。 診断は, X線検查, 内視鏡検查, 生検, 細胞診の各々 で， m, sm 癌よりも容易で，上り高度な癌と同様の陽 性率を示した。 $\mathrm{pm}$ 癌の内視鏡所見は，平㿼状の広基底 性ポリープ（病変全体が，内視鏡で観察できる程の小さ なもの） 9 例， $33.3 \%$ ，大きな腫瘤 4 例， $14.8 \%$, 癌火 口11例， 40.7\%，輪状狭窄（全周性の狭窄で瀆瑝の確認 できないもの） 3 例， $11.1 \%$ で，平血状ポリープの 9 例 中 8 例で，表面の陷凹が認められた，また，病変部を越 して，口側の正常粘膜を観察できるものが， $81.5 \%$ ( $\mathrm{sm}$ 癌100\%，ss，a癌36.1\%）であった.

以上より，大腸癌の予後を改善するためには，積極的 に, $\mathrm{m}, \mathrm{sm}$ 癌の発見に努める一方, 診断が容易で, 予 後の良好な $\mathrm{pm}$ 癌を見逃さないことが重要であるとの， 結論を得た。

\section{SI-4. 大腸癌の早期診断}

\section{東京都立駒込病院内視鏡㠁断科 田島強}

同内科
Colonofiberscope 開発以来，この11年間に経験した大 腸癌 318例について内視鏡診断を中心に検討を加え, 進 行癌を含めた大腸癌の早期診断とその問題点について述、 ベた.

大腸進行癌の内視鏡診断は容易であるが，狭い管腔に 大きく発育した腫瘍の全貌を観察できる症例は少なく, 全景を観察できたものは1/3強にすぎなかった. 通常スコ 一プで観察が不充分な例では，細径の回腸用スコープや 
広視野角スコープが有用であった．内視鏡像と切除標本 との比較では，管腔内の腫瘍の抾がりについては一致す ることが多かったが，獎膜侵潤については推定困難であ った.

大腸早期癌例は，全例隆起性病変であり，そのほとん どが大腸ポリープにみられた局在癌であった，その鑑別

は，内視鏡的には不可能に近く，直視下生検も微小局在 癌には無力である.したがって，大腸早期癌を診断する ためには，大腸ポリープを見つけ出し，内視鏡的に切除 し，病理組織学的に榆討することが必要である、今まで に255個のポリープを内視鏡的に切除し，23個に早期癌 を診断したが， $1 \mathrm{~cm}$ 以下のポりープにも早期癌が少な からず診断されている。

内視鏡的ポリープ切除の問題点として，第一に切除䣫 後の偶発症があげられる．本法は $100 \%$ 安全法でないと いらことを念頭におきながら，それに対好出来る状態で 行らべきである. 次いで，長期間経過してからの再発が 問題となるが同一部位再発は経験していない。しかし， 大腸早期癌の多発ポリープ例で注，切除後 1 年以上経過 観察した 9 例中 7 例に他部位に新しいポリープが見られ ており，多発ポリープ例では十分な経過観察が必要であ る. 症例を供覽しながら述べた。

\section{SI-5. 大腸早期癌の病理組䢂学的特徵と治療方 針}

\section{東京大学第 1 外科}

武藤徹一郎，上谷潤二郎，沢田 俊夫 草間・悟

手術操作から見出された早期癌21病变，内視鏡的ポリ ペクトミーによって発見された早期癌 49 病変の病理組織 学的検菜の結果，大腸早期輹は隆起型と謴煌型とに大別 できることがわかった. 隆起型の大多数は腺膜内癌であ り，漬湯型ではその率は50\%以下となる：ポクペクトミ 一標本の検索から，隆起型には有菱性と無茎性，亜有茥 性のものがあり，後者の頻度が全体の50\%以上を占めて いること， $2 \mathrm{~cm}$ 以下のものが70\%を占めていることが わかった. $1 \mathrm{~cm}$ 以下の腺腱にも約 $7 \%$ 癌化率が認め られた. 腺腫の連続切片標本の検索から，腺腫内の小症 夈はしばしば複数存在すること，癌宩が表面に露出して いないこともあることがわかった，したがって，ポリー プは見つけ次第その大きさの如何に拘らず内視鏡的摘除 生検として摘除するのが正しいと考えられた. 降起型早 期癌の周围粘膜に認められる白斑の存在は，摘除前の良 性悪性判定の一助になる可能性がある.

早期癌の中m癌はリンパ節軽移をしないので摘除生検
によって治療も完了してしま5。 $\mathrm{sm}$ 癌の中で転移を起 こしている大多数は潰瘍型であり，隆起型のものからの 転移は稀である，しかし，粘膜下リンパ管侵襲のあるも の，低分化癌，断端にまで癌侵潤の及んでいるものは経 験的に転移の危険性が高いので，腸切除の適応があると 考えられている．腸切除を追加するか否かは，以上の諸 条件をもとに患者の全身状態，腫演の位置などを考慮に 入れ，腸切除を追加すること，しないことのメリット， デメリットを一例一例慎重に検討して決定すべきであ る.われわれは12例の $\mathrm{sm}$ 癌の中 3 例に腸切除を追加 L たが，癌遺残，リンパ節転移は見出されなかった。残る 9 例は最長 4 年に至るまで健在である。

\section{SI-6. 大腸早期癌の診断と治療方針}

横浜市立大学第 2 外科

松田 好雄, 大本 繁男, 大尾 武彦 土屋 周二

大腸早期癌は，胃早期癌に比べ，リンパ節転移率が低 く，外科治療によりほぼ完治が得られその予後は非常に

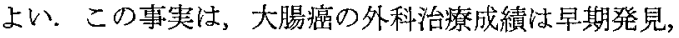
早期治療により飛躍的に向上することを示唆している.

今回，自験大腸早期癌51例扝よびわれわれが収集しえ た本邦での報告例204例，計255例の大腸早期癌症例に臨 床的検㖊支加え，本症の臨床的特徽，治療方針に関して 若干の知見を得たので報告する．大腸早期癌の臨床的特 徵についてみると，本邦での頻度は全大腸癌の $6 \%$ ，わ れわれの施設では $12 \%$ と高頻度であった。主たる臨床症 状は下部消化管出血で，男女比は 1.6:1 と男性に多い 傾问であった，大腸の良性腺腫， $\mathrm{m}$ 癔扔よざ $\mathrm{sm}$ 癌症例 の平均年龄は，それぞれ49才，56才抢よび60才と加踰に よる腺腫の癌化が推定された，肉眼的形態は，大多数が ポリープ状隆起. (有萣型，烸茎型，扁平隆起型）を呈 し，潰瘍形成型は 10例（4\%）にすぎない，部位別に は，直腸では157例中，有茥型31\%（5ち sm癌29\%)， 無茥型49\% (56\%) および扁平隆起型20\% (67\%) であ り，結腸では98例中それぞれ57\% (11\%)，30\% (52\%) および13\%（82\%）であった，潰瘍形成型は全例 sm 癌 であった. 大きさ (最大径) を加味してみると，直腸で

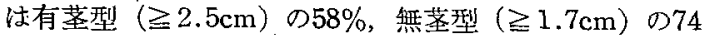
$\%$, 扁平隆起型 ( $\geqq 1 \mathrm{~cm})$ の $86 \%$ は $\mathrm{sm}$ 癌であった. しかし結腸では大きさと樑達度との関連性は認められな かった。鉗子生検による癌陽性率任 $\mathrm{m}$ 癌で33\%と低率で あるのに比へ，sm癌では76\%と高率であった，以上の 結果より大腸のポリープ状隆起性病変の診断は，ほぼ可 能であり，下血を主訴とする症例に刘しては積極的に大 
腸精查を行い早期に病変を見つける努力を行えば，大腸

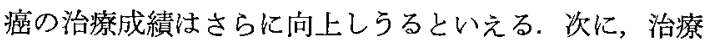
方針に関しては， $\mathrm{m}$ 癌に対しては，事実上リンパ節転移 がないことからポリペクトミーをふくめた局所切除で完 治がえられる．自験 $\mathrm{m}$ 癌30例に再発は認めてない. $\mathrm{sm}$ 癌に対しては，ポリペクトミーをはじめ種々局所切除

（結腸病变に対しては，腸管切除，wedge resection な そ， 直腸病変に対しては，経肛門的局所切除，経括約筋 的ないし経仙骨的局所切除）を腫場占居部位，肉眼的形 態を参考に施行し，以下の条件 (1)切除断端に癌を認め ない(2)固有筋層を含め十分切除されている(3)陷凹ないし 潰湯形成がない(4)リンパ管侵潤がない(5術中の視触㟝で リンパ節転移が認められない(5)組織型が低分化型ないし 未分化でない，をすべて満足する場合は，さらに根治術 を付加せず厳重な follow up を行っている，現在，局 所切除施行 sm 癌14例に再発はない. ことに直晹病変に 対しては上記治療方針を適応と考えている．以上，大腸 早期涭の診断ことに臨床的特微についてのべ，これを子 まえた外科治療方針に関する考え方を報告する。

\section{SI-7. 早期大腸癌の診断と治療（人間ドックに おける直腸鏡検查の経験と外科的治療の 反省）}

鹿先島大学第 1 外科

吉井 紘興, 西 満 正, 石 沢 隆 桑原 大祐, 上原 尚人, 吉見多喜雄 加治 . 佐隆

本邦では大腸癌の中でも直腸癌が多いといわれてき た. 人間ドックに㧍いて直腸鏡检查を施行し，早期直腸 癌の発見に努めてきた。昭和49年10月より昭和54年 8 月 まで5,036人の受診者があった. 男 4,522 人，女514人で あり，30才台 737 人，40才台 2,130 人，50才台 1,865 人， 60才以上 304 人であった. 282 例に何らかの隆起性病変が みられ，腺管腺腫が95例 (1.9\%) にみられた. 腺管腺 腫の発生は，50才台で最も多くみられ3\%台の嚬度をみ た. 8 例の癌が発見され， 3 例の進行癌上 5 例の腺腫内 漚が発見された， 2 例の進行癌症例を除いては全例が無 症状であり，直腸鏡は直腸病変のスクリーニングに極め て有用であった．腺腫内癌は肉眼的には腺腫との鑑別は 不可能であった.

進行癌を合併しない大腸早期癌の33例39病変を経験し た. $\mathrm{m}$ 癌 21 症例 27 病変, $\mathrm{sm}$ 癌12症例である. $\mathrm{m}$ 癌の ち 14例は有茎性であり，9例は亜有茎性であった. II 様の 2 病変が経験されたが, prospective にも retrospective にも注腸透視の二重造影で指摘されえなかっ
た. $\operatorname{sm}$ 澞は Is ないし II 様の病変であった.

治療は直腸では Miles 手術が12例に, polypectomy が 4 例に行われ，他はいずれを腸の部分切除か局所切除 が行われた．検索されたリンパ節には，いずれもリンパ 節転移はみら机なかった，m 澞の治療では polypectomy や局所切除で十分な場合が多いが， sm 癌で注粘膜 下層にリンパ管侵襲が証明されて扔り，組織学的に十分 検索し，リンパ管侵襲や低分化癌では進行癌に準じた治 療が必要であると思われた。

\section{SI-発言 1. 大腸癌早期診断のための臨床的検討}

\section{東京医科大学内科 酒井 義浩，沖田 琇二}

大腸癌 269 例 273 病変の占居部位值直腸 $90, \mathrm{~S}$ 状結腸 86, 下行結腸 21 ，横行結腸 22 , 上行結腸 36 , 盲腸 18 であ る. この内 31 病変は早期癌で II $a+$ II c 型 6 , II a 型 2 , I 型23で，18病変は polypectomy によって完全生検し た. 年龂分布上 70 才代まで早期癌が存在するが，若年者 ほざ polypectomy にて発見される頻度が高く, polypectomy の適応となる I 型が多い，一方外科的切除に て早期癌を確認したものは40才代 $2.9 \%$ ，50才代 $3.8 \%$, 60 才代 $4.9 \% ， 70$ 才代 $6.7 \%$ と増加して招り，加齢と共に polypectomy の適応とならない II $\mathrm{a}+\Pi \mathrm{c}$ 型が増加し ている. 従って polyp の年龄分布と関連して，中高年 の隆起性病変を検出する目的でX線的・内梘鏡的検索は 重要であり，積極的に polypectomy を行らことが早期 治療に連ることを示唆している.

進行癌を早期に発見することは予後に重要なことは明 白であり，このための検索を受ける契機が閭題となる. 大腸癌で血便を主訴とする頻度は $41.7 \%$ であり，進行癌 では $40.4 \%$ である. 若年性 polyp $88.9 \%$ ，漬愓性大腸 炎 $67.5 \%$ ，放射性直腸炎 $64.7 \%$ に比し少い，進行癌の占 居部位による血便の出現頻度は值腸が最多で $64.1 \%$, 次 いでS 状結腸 $55.3 \%$ ，右側結晹では $5 \%$ 前後である，直 腸 $\mathrm{S}$ 状結腸の進行癌に限って内視鏡的形態と血便期間ま たは環周度を検討すると，約半数が 1 ケ月から 1 年の病 悩期間のほぼ全周性の Borrmann II 型であったが, 多 彩であり，経過中全く血便に気付かない例も約10\%存在 した．後者の主訴は貧血であり，下痢であり，便通異常 であった.

従って中高年にみられる血便は直腸 S 状結腸癌である 可能性を考慮して，X線的に描出しにくい同部を積極的 に内視鏡検查することが進行癌の早期診断へ導くである 5. その他便通異常に関する愁訴，貧血，腹痛に対して は反復する潜血検査や深部大腸観察を含めた全大腸の検 
索をすすめるべきである.

\section{SI-発言 2. 大腸癌早期発見のための家族歴の検 討}

国立大阪病院

吉川 宣啭，笹井 平, 水野 滋 岡崎晃

大腸癌の mass screening は，その検查手段が特殊で あり，その罹患率もまだ低いことから，無作為の集団を 対象とするのが困難である. 従って，大腸癌発生のhigh riskにある group を検診するという，いわゆる selective mass screening の考え方が必要となる.この selective mass 描出の手段として，年踰，職業等多くの因 子が考えられるが，私共は家族集積性という面から検討 した.

大腸癌321症例の家族歴をアンタート用紙等で調査し， sampling の胃癌112症例と人口動態統計からの推計值を control とした.

大腸癌患者では家族内に大腸癌による死亡者を有する むのが多く，とくにその父親は general populationの $3 \sim 4$ 倍高率に大晹癌で死亡している. 胃癌にも家族集 積性老認めるが，胃癌と大腸癌には相関々係はない，男 の大腸癌家族例では父親，兄弟との関倸が強く，女の大 腸癌家族例では母親，姉妹との家族性が強い，家族内発 性を有する症例では重複癌が多く，とくに大腸に同時 性，異時性の多発癌をみることが多いまをた家族内発生 例では癌の周辺に孤立性の腺腫を合併する頻度が著しく 高い.

以上のことから，家族内に大腸癌を有寸る者は大腸癌 発生の high risk group と考它られる. 従って，大腸 癌の早期発見のための selective mass screeningには, 家族歴をも付け加えて考えることが大切である.

\section{シンポジゥム 1 : 座長のまとめ}

弘前大学第 1 内科

吉田 豊

鹿児島大学第 1 外科

西満正

種々のデーターからして，わが国に㧅いて米国や西 ドイツに扔けると同様に，大腸がんの発生が増えている ことは確䒠であり，これを早期に発見して治療すること は今や国際的な研究課題となっている. 上昇しつつある 死亡率を下降させようとする最終目標に向って一歩でも 二歩でも近づくことにこのシンポジウムが役立てばとい らことで各発表に期街した。

Mass screening : 発生頻度と費用加らしても対象は 40 才以上が適当だらうとの意見であった. 方法は内視鏡に よる方法が理想ではあるが，大きな mass の消化が不可 能であるとのことで，家族歴や潜血反応による screening の方法が討議された。早期がんの発見には侸陰性が 多すぎる潜血反応も早期がんに近い予後成績をもつ pm 癌や Dukes A 癌を目標にすることで有用性が期待され た.

部断のための形態特徵：有茎性，亜有茎性の $\mathrm{m}$ 癌, sm 癌は内視鏡的ポリペクトミーだけで治療的にも十分 であろうし，扁平性また浊潰愓性 sm 癌では外科的切除 が必要であらうとの意見でシンポジストは一致した。 clinical とはいえないが，早期がんの病態の基礎的研究 のためにも内視鏡的桩大観察法などによるポりープ表面 の詳細な観察が必要であるとの意見もあった.

治療：内視鏡的ポリペクトミーか外科的局所治療かと の砷議でも，有茎性，亚有茎性では先ず前者で治療し， 組織学的に断端部の浸潤や高度の未分化湲の場合にのみ 追加切除を行うべきとする意見が強かった，いずれにせ 上, 他の部位での發生の可能性も大きいので follow-up が大切なことが強調された。

最後に松永藤雄先生の特別発言があり，大腸がんの登 録などは国家的事業として行なうよう学会として国へ働 きかけるべきであるなどの学会に対する 2,3 の宿題も 頂きシンポジウムを終了した. 


\title{
Symposium I
}

\section{SI-1 Early Detection of the Colorectal Cancer}

\author{
T. Aisawa, and A. Munakata
}

First Department of Internal Medicine, Hirosaki University School of Medicine, Hirosaki

Mass screening by proctoscopy and occult blood test was performed in order to detect early cancer of the rectosigmoid colon.

From July 1972 to March 1979, mass screening by proctoscopy was done in 16 rural villages and towns arround Hirosaki city in Japan.

From December 1976 the occult blood test examination was added with occult blood slide containing reagents for orthotolidine and guaiac reaction.

From July 1972 to March 1979, 8,554 cases were examined: 2,541 cases of male and 6,013 of female. Abnormalities were found in 218 cases $(2.55 \%)$.

The findings were as follows:

Carcinoma $9(0.11 \%)$ (including 6 early cancers), polyp or polyposis $174(2.0 \%)$, colonic diverticular disease $3(0.04 \%)$, colonic melaanosis $28(0.33 \%)$ and others 4 cases $(0.05 \%)$. In the 5,844 cases screened by first occult blood test, 890 cases $(15.2 \%)$ were positive, and 251 patients $(4.3 \%)$ were positive again in the second test, 182 of whom the barium enema or colonofiberscopy study was performed. In this examination, 1 case of colonic cancer, 6 cases of colonic polyp ( 9 lesions), 4 cases of diverticular and 2 cases of lymphfollicle hyperplasia were detected.

We believe that mass screening test by proctoscopy and occult blood test is reliable and rewarding in early detection of rectosigmoid cancer.

\section{SI-2 Screening for Colo-Rectal Cancer}

\author{
M. Tada
}

Kyoto First Red Cross Hospital, Department of 3rd Internal Medicine, Kyoto Y. Akasaka

Kyoto Prefectural University Medicine, Department of Preventive Medicine, Kyoto

Recently, according to the change of our environmental factors such as diet and habits and the improvement of colon diagnostics, colo-rectal cancer has been increasing in Japa- 
nese as in American and European. Therefore, the screening system as gastric mass survey regime should be established as quickly as possible.

Endoscopic screening for the lower part of the colon using a flexible sigmoidofiberscope (TCF-1s, CF-1TS, Olympus) were performed in our clinic. Screening for colon cancer was easily and effectively performed with minimal bowel preparation, and not only cancer but also several colon diseases were detected.

Therefore, it is emphasized that for the early detection of colon cancer, the screening examination using a sigmoidofiberscope should be performed regardless to their complaints or age.

\title{
SI-3 pm Cancer of the Colon and Rectum: Its Significance and Diagnosis
}

\author{
K. Shoji \\ Third Department of Internal Medicine, Tohoku University School of Medicine, Sendai
}

The relative 5-year-survival rate of $33 \mathrm{pm}$ cancer cases was $92.3 \%$ and 10 -year-survival rate $90.3 \%$. In 29 cases. with no lymph node involvement, they were $99.5 \%$ and $96.1 \%$ each, a figure close to that of normal control.

The results of radiological diagnosis, endoscopic diagnosis, biopsy and cytology showed that $\mathrm{pm}$ cancer was easily diagnosed as more invasive cancer, while the diagnosis of early cancer ( $m$ ca. and sm ca.) was difficult.

For excellent prognosis of cancer of the colon and rectum, it is important never to miss pm cancer and to make an effort to detect early cancer.

\section{SI-4 Early Diagnosis of the Colonic Cancer}

T. Tajima and J. Ishiwata

Tokyo Metropolitan Komagome Hospital, Tokyo

Eary diagnosis and its problems of the colonic cancer, including advanced cancer, were studied endoscopically based on our experienced of 318 cases of the colonic cancer diagnosed by colonofiberscopy. 
Endoscopic diagnosis of advanced cancer of the colon was technically easy, however the whole lesion of each tumor was observed only in $30 \%$ of all cases completely. Ileoscopy with small diameter and special scope with wide view angle were useful in such cases.

All lesions of early colonic cancer were protruded and the majority of those were focal cancer in adenoma. Differential diagnosis of adenoma and focal cancer of the colon. was almost impossible endoscopically, and usual biopsy under visual control was not so useful to detect minute focal lesion. So endoscopic polypectomy was necessary for complete total biopsy. It might be the best way for diagnosis of early colonic cancer to resect endscopically every polypoid lesions if possible, and to examine those resected specimens in detail pathologically.

So far we have done endoscopic polypectomy in 235 lesions of the colon and diagnosed 23 lesions with early cancer. Several lesions of those were less than $1 \mathrm{~cm}$ in max. diameter.

There are some problems on endoscopic polypectomy. The first one is accidents caused by polypectomy such as massive hemorrhage and perforation. We experienced 4 cases with massive hemorrhage; one case was operated and the other 3 cases were treated without operation. It might be better to do polypectomy under hospitalization.

The second problem is recurrence or new born of polypoid lesion after polypectomy. We have not experienced recurrence after polypectomy, however new polypoid lesions were found out in 7 cases of early cancer with multiple polyps on periodic endoscopy over than one year after polypectomy. In cases of polypectomy, special emphasis should be put on periodical endoscopic follow-up for long term study.

\title{
SI-5 Histopathological Features and Management of Early Colorectal Carcinoma
}

\author{
T. Muto, J. Kamiya, T. Sawada, and S. Kusama \\ Department of Surgery, University of Tokyo, Tokyo
}

Twenty one early carcinomas from the operative specimens and 49 from the polypectomy series were histologically investigated in order to find pathological features of early carcinoma of the large bowel, and they were classified into two main types, polypoid and ulcerating. The former was subdevided as pedunculated and semipedunculated or sessile. Almost all polypoid early carcinoma had histological evidence of carcinoma in adenoma whereas in ulcerating type the rate was less than 50\%. Among polypoid type semipeduculated type was most common and $70 \%$ was under $2 \mathrm{~cm}$ in diameter. Adenomas even under 
$1 \mathrm{~cm}$ in diameter had malignant potential as high as $7 \%$. From the histological investigation of serial sections of adenomas it became apparent that there were multiple focus of minute carcinoma in some adenomas and they were not always exposed to the surface. Therefore, polypoid lesions should be removed as soon as possible regardless of their size or site for excision biopsy.

White spots frequently seen in the mucosa around carcinoma may be useful aid for suspecting the presence of cancer focus in a presumably benign polyp.

Ulcerating type of early carcinoma has potential of lymphnode metastasis whereas polypoid type has little potential. However, under such condition as below it has potential of metastasis and further radical operation should be considered, that is 1 ) lymphatic permiation of the submucosa, 2) poorly differentiated carcinoma, and 3) carcinoma invading close to the cut end. Carcinoma confined to the mucosa and invading through the muscularis mucosae without histological evidence of such condition mentioned above, the growth is safely treated by local excision (polypectomy) only.

\title{
SI-7 Diagnosis and Treatment of Early Colorectal Cancer: Specially Referenced to Romanoscopy in Human Dock and Treatment of Early Cancer
}

\author{
H. Yoshii, M. Nishii, T. Ishizawa, D. Kuwabara \\ H. Uehara, T. Yoshimi, and T. Kajisa \\ First Department of Surgery, School of Medicine, Kagoshima University, Kagoshima
}

It is reported on usefullness of romanoscopy for screening of rectal lesion in human dock and diagnosis and treatment of early colorectal cancer.

Romanoscopy was performed on 5036 persons, 282 out of whom were detected polypoid lesions. Three advanced cancers and 5 adenomas with cancer were out of 282 polypoid lesions. Frequency of incidence of tubular adenoma was 1.9 percent and higher in fifth decade.

Thirty three cases of early colorectal cancer were reported. Two cases had multiple carcinomatous lesions. Two lesions of IIc type were detected on a patient with multiple polyps. These lesions were not able to detected prospectively nor retrospectively on double contrast barium enema. Almost of early colorectal cancers were polypoid, 4 cases were ulcerative. Treatment of carcinoma in adenoma may be enough only to remove polyp. Treatment of cancer invaded to submucosal layer without lymphatic permiation which is 
well differentiated, may be excised locally, but poorly differentiated or with lymphatic permiation, it should be treated as advanced cancer.

\title{
SI-Suppl. 1. Clinical Evaluation for Early Diagnosis of the Colorectal Cancer
}

\author{
Y. Sakai, and S. Okita \\ Tokyo Medical College Hospital, Tokyo
}

Two hundred and seventy three lesions of the colorectal cancer in 267 cases were detected endoscopically for last 10 years. Distribution of lesions was as following; rectum 90 , sigmoid 86, descending colon 21, transverse colon 22, ascending colon 36 , and cecum 18 . Of these, 31 lesions were early cancer which cancer invasion limited into the mucosa or submucosa. Eighteen of them were polypectomized endoscopically. Although early cancer was recognized in 8th decades group, polypectomy was done rather frequently in younger age group. Active endoscopic examination is important to find polyp especially in middle age group and polypectomy is quite useful to diagnose and treat them earlier.

However, problem is to find advanced cancer in early stage. Although bloody stool would be a land mark for carcinoma, frequency was rather lower than others. Correlation between bloody stool and endoscopic finding or its growing rate was negative. Another symptoms of advanced cancer were very variable. Therefore, endoscopy is recommended when elder age group complained bloody stool to rule out cancer in rectosigmoid area which was difficult to reveal in barium enema. Even in another symptoms, repeated fecal occult blood test or total colonoscopy is recommended to find advanced cancer in more early stage.

\section{SI-Suppl. 2 Studies of Family History for the Early Detection of Colo-Rectal Cancer}

\author{
N. Kikkawa, S. Mizuno, T. Sasai and A. Okazaki \\ Osaka National Hospital, Osaka
}

Mass screening is effective for the early detection of cancer, but in the mass screening of colo-rectal cancer, many difficulties are encountered when the subjects are in randomly 
selected groups. Therefore, it is necessary to introduce the concept of "selective mass screening" in which groups with a high risk incidence of colo-rectal cancer are examined. We investigated the family as one of these risk factors.

Materials and methods:

A questionnaire survey was performed concerning the family history of 321 colo-rectal cancer patients. As controls, 112 sampled gastric cancer patients and the incidence in the general population estimated from vital statistics were used.

Results:

1) Many of the family members of colo-réctal cancer patients died of colo-rectal cancer and the incidence of colo-rectal cancer, particularly when the father died of it, was 3-4 times that of the general population.

2) Among males cases in a family, there were strong relations with father and brothers, while among female cases, there were strong relations with the mother and sisters.

3) The average age of cases occuring within a family was eight years younger than the average age of cases not within a family.

4) Among the cases occurring within a family, there was a high incidence of multiple cancer and an especially high incidence of synchronous colo-rectal cancer.

5) In familial cases, there were often solitary adenomas in the vicinity of the primary lesions.

From the above results, those with colo-rectal cancer patients in their families are in a high risk group of colo-rectal cancer incidence and should be the subjects of selective mass screening. 